\title{
TRICHINELLA SKIN TESTS IN AN ORPHANAGE AND PRISON. COMPARISON WITH SEROLOGIC TESTS FOR TRICHINOSIS AND WITH THE TUBERCULIN REACTION ${ }^{1}$
}

\author{
By GEORGE T. HARRELL, S. F. HORNE, JERRY K. AIKAWA, \\ AND NANCY J. HELSABECK \\ (From the Department of Medicine, Bowman Gray School of Medicine of Wake Forest \\ College, Winston-Salem)
}

(Received for publication August 5, 1946)

The possibility that an unrelated disease process may alter the reaction to the trichinella skin test was uncovered in the course of an investigation on the incidence of trichinosis. A higher percentage of positive skin reactions to trichinella antigen (18.3 per cent) was obtained in 674 patients with active tuberculosis confined in 3 sanatoria, than was found in 335 patients without tuberculosis (7.2 per cent) studied in 2 general hospitals for shorter periods of time (1). On the other hand, the incidence ( 18.4 per cent) in 825 patients without active tuberculosis confined in 3 hospitals for mental diseases was almost identical with that found in the sanatoria. This finding suggested that some factor connected with residence in an institution might account for the high incidence. An analysis of positive reactors according to the duration of stay in an institution revealed that the incidence of positive reactions reached a peak at 18 to 29 months; no history suggesting subclinical institutional epidemics was elicited (1).

Experiments were undertaken to determine whether positive trichinella skin tests could be produced in the absence of infection by the ingestion of killed trichinae, as in meat rendered noninfectious by cooking inadequate to denature the protein of the parasite. Sensitization was not induced in the animals used for these experiments (2). The possibility of a biologic cross reaction, detectable by skin test, between Mycobacterium tuberculosis and Trichinella spiralis was investigated in rabbits infected with trichinae and a bovine strain of tubercle bacilli simultaneously. No cross reaction was detected in these rabbits by skin tests (3).

The present experiments were undertaken to determine whether a biologic cross reaction de-

1 This study was aided by a grant from the John and Mary R. Markle Foundation. tectable by skin test might be demonstrated in human beings. It was necessary to select subjects for testing who did not have active tuberculosis or acute psychiatric disturbances (1). In order to control adequately the factor of age in institutionalized individuals, it was desirable to choose one institution in which only children were in residence, and one institution where only adults were confined for comparable periods of stay. It had been found that the incidence of positive skin reactions decreases with advancing age, whereas the incidence of infection proved at autopsy increases with advancing age (1). An orphanage and a prison, both under close medical supervision, most nearly met the requirements.

\section{MATERIAL}

A total of 526 individuals were subjected to skin tests. Each person had been in residence in the institution for at least one year; the majority had been in residence for 2 to 15 years (Table III). In none was there a history of tuberculosis or of recognized mental disease. No patient was known to have had trichinosis, and there had been no epidemics in either institution which suggested trichinosis.

At the Methodist Children's Home, Winston-Salem, N. C., 285 children, varying in age from 6 to 19 years, were tested. The children are all white and are housed according to age in groups of 25 to 35 in 13 cottages; every 2 years they "graduate" from one cottage to another, so that the group is fairly homogeneous. Though there are kitchens in each cottage, only 3 are currently used to feed groups of boys included in this study. The remainder of the boys and all of the girls eat in a central dining room. Pork obtained from hogs raised on the orphanage farm is served twice weekly from November to February; the children eat little pork and prefer beef, which is also available. Routine chest $x$-rays are not made, but none of the children found to have a positive tuberculin skin test had clinical or roentgenologic evidence of tuberculosis when examined subsequently.

In the North Carolina Central Prison, Raleigh, N. C., a group of 241 prisoners, varying in age from 16 to 77 years, was studied. The 58 female prisoners are housed 
in a separate building with a separate kitchen; hence, this group in effect represents 2 institutions. No prisoner had roentgenologic evidence of pulmonary. tuberculosis when a photo-roentgen survey was made a few months prior to the initiation of this study. Pork raised on the prison farm is served once weekly. The quantity of pork eaten at the prison appears to have been slightly greater for the 2 years preceding the test than that eaten at the orphanage.

\section{METHODS}

In all instances, a 1:10,000 solution of trichinella extract (Lederle) and a phenolized phosphate buffer saline control solution were used.2 A 1:1,000 dilution of tuberculin (Lilly) in distilled water and the tuberculin control solution were freshly prepared for use in each institution.

New syringes and needles were obtained for the skin tests, and were not used for any other purpose. One syringe and needle was always used for each test solution, and 2 others for the controls; the syringes and needles were never interchanged. After being used, they were washed with distilled water only, placed in marked tubes, and sterilized in an autoclave.

An area on the flexor surface of both forearms was cleaned with 70 per cent alcohol, and 4 workers simultaneously injected $0.02 \mathrm{ml}$. of the trichinella test and control solutions in the right arm, and $0.1 \mathrm{ml}$. of the tuberculin test and control solutions in the left arm. The test solution was always injected proximal to the control solution.

The reactions were read at 30 minutes and 24 hours after injection. The tuberculin reactions were graded by the usual scale from 1 to 4 plus. The trichinella reactions were also recorded on a scale of 1 to 4 plus, 1 plus denoting an immediate reaction which exceeded the diameter of the injected bleb by $5 \mathrm{~mm}$. or more (1).

2 The trichinella antigen and control solution used in this study were supplied by Lederle Laboratories, Pearl River, N. Y.
Ten weeks after the skin tests were performed, blood serum was drawn from the antecubital vein of the orphans for serologic testing. Serum was obtained from the prisoners 17 to 19 weeks after skin-testing.

Flocculation tests were performed according to the technique described by Suessenguth and Kline (4). The trichinae from which the antigen was prepared were recovered from rabbits fed 8 weeks previously on a rat infected with a strain of trichinella parasites obtained from the National Institute of Health (2). Precipitin reactions were done with a $1: 200$ dilution of antigen prepared from the same dried trichinae used for the flocculation test.

\section{RESULTS}

Skin tests

Orphanage. Fifty-seven children (20.0 per cent) gave positive trichinella skin tests; 51 were immediate reactions, and 9 were delayed reactions which appeared at 24 hours. Three tests were positive at both 30 minutes and 24 hours (Table I). Seven children reacted to both the test and control solution, and were calculated as negative in the statistical analysis. Forty children (14.0 per cent) gave positive tuberculin reactions at 24 hours. The immediate reactions to the tuberculin test and control solution were not thought to be significant. Six children reacted positively to both trichinella extract and tuberculin, and negatively to both controls. One hundred and ninety-five children gave negative reactions to all antigens at both times.

Prison. Sixty-five prisoners (27.8 per cent) gave positive reactions to trichinella antigen at some time (Table I). Fifty-two were immediate

TABLE I

Summary of trichinella and tuberculin skin tests

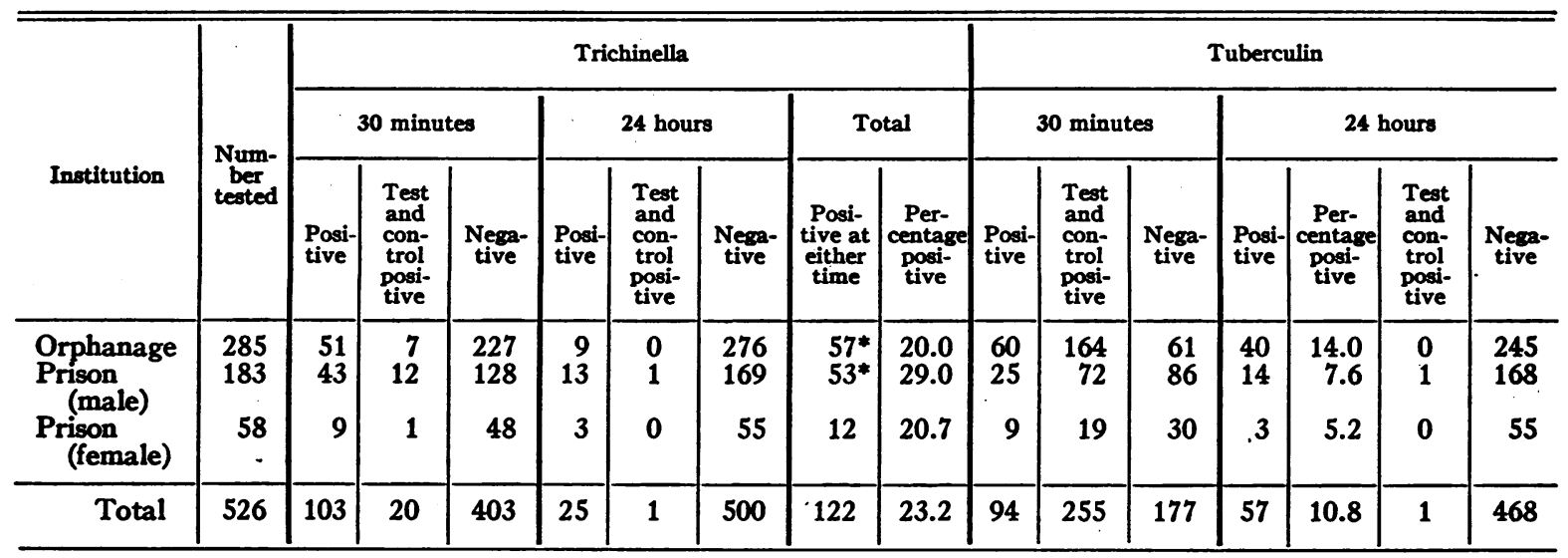

* Three patients had positive reactions at both $30 \mathrm{~min}$. and $24 \mathrm{hrs}$. 
reactions, and 16 were delayed. Three were positive at both 30 minutes and 24 hours. Thirteen prisoners gave positive reactions to both the test and control solution at 30 minutes. Seventeen prisoners (7.1 per cent) had delayed reactions to tuberculin. Two prisoners reacted to both tuberculin and trichinella antigen, and did not react to the control solutions. One prisoner gave a positive reaction to both tuberculin and the tuberculin control solution at 24 hours. One hundred and sixty-three prisoners reacted negatively to all antigens at both times.

TABLE II

Comparison of tuberculin and trichinella skin tests

\begin{tabular}{|c|c|c|c|c|c|c|}
\hline \multirow{2}{*}{ Institution } & \multirow{2}{*}{$\begin{array}{c}\text { Trichinella } \\
\text { positive } \\
\text { (either } \\
\text { time) }\end{array}$} & \multicolumn{5}{|c|}{ Tuberculin (24 hrs.) } \\
\hline & & $\mathbf{0}$ & $1+$ & $2+$ & $3+$ & $4+$ \\
\hline Orphanage & $\begin{array}{l}0 \\
1+ \\
2+ \\
3+ \\
4+\end{array}$ & $\begin{array}{r}195 \\
21 \\
14 \\
9 \\
6\end{array}$ & $\begin{array}{r}23 \\
3 \\
1 \\
1 \\
0\end{array}$ & $\begin{array}{l}9 \\
1 \\
0 \\
0 \\
0\end{array}$ & $\begin{array}{l}1 \\
0 \\
0 \\
1 \\
0\end{array}$ & $\begin{array}{l}\mathbf{0} \\
\mathbf{0} \\
\mathbf{0} \\
\mathbf{0} \\
\mathbf{0}\end{array}$ \\
\hline $\begin{array}{l}\text { Prison } \\
\text { (male) }\end{array}$ & $\begin{array}{l}0 \\
1+ \\
2+ \\
3+ \\
4+\end{array}$ & $\begin{array}{r}120 \\
19 \\
16 \\
11 \\
3\end{array}$ & $\begin{array}{l}9 \\
0 \\
2 \\
0 \\
0\end{array}$ & $\begin{array}{l}1 \\
0 \\
0 \\
0 \\
0\end{array}$ & $\begin{array}{l}0 \\
1 \\
1 \\
0 \\
0\end{array}$ & $\begin{array}{l}0 \\
0 \\
0 \\
0 \\
0\end{array}$ \\
\hline $\begin{array}{l}\text { Prison } \\
\quad \text { (female) }\end{array}$ & $\begin{array}{l}0 \\
1+ \\
2+ \\
3+ \\
4+\end{array}$ & $\begin{array}{r}43 \\
7 \\
2 \\
3 \\
0\end{array}$ & $\begin{array}{l}2 \\
0 \\
0 \\
0 \\
0\end{array}$ & $\begin{array}{l}1 \\
0 \\
0 \\
0 \\
0\end{array}$ & $\begin{array}{l}0 \\
0 \\
0 \\
0 \\
0\end{array}$ & $\begin{array}{l}0 \\
0 \\
0 \\
0 \\
0\end{array}$ \\
\hline
\end{tabular}

Since the interpretation of immediate and delayed reactions to trichinella antigen is still in doubt, positive reactions at either period were compared with late tuberculin reactions (Table II). No correlation between positive reactions to tuberculin and trichinella antigen was found.

The data were tabulated according to the extent of the trichinella reaction and the duration of stay in each institution (Table III). The duration of stay in an institution did not appear to affect the extent of the trichinella reaction. When the percentage of positive trichinella reactions was tabulated according to years of institutionalization, the incidence was found to be highest in the orphanage at the second and fifth years, with a secondary peak at the ninth year. In the prison, the peak incidence was reached at the sixth year.

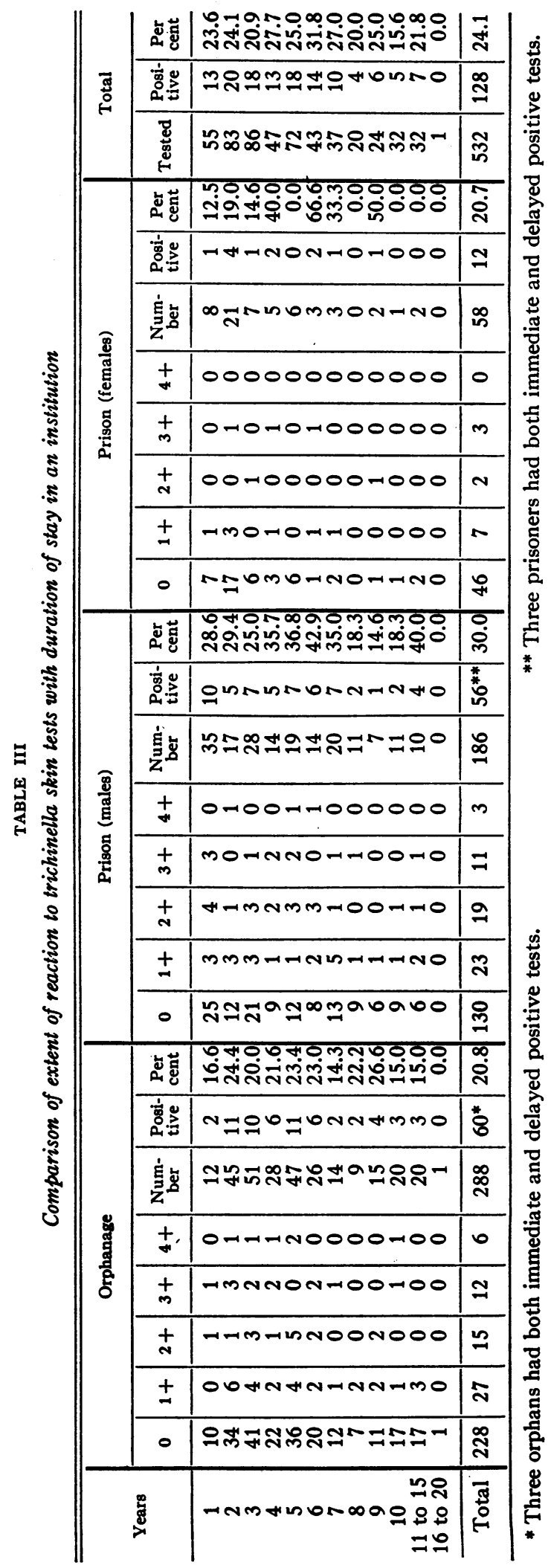


TABLE IV

Comparison of serologic reactions for trichinosis with skin tests

\begin{tabular}{|c|c|c|c|c|c|c|c|c|c|c|c|c|c|c|c|c|c|c|c|c|}
\hline \multirow{3}{*}{ Institution } & \multicolumn{7}{|c|}{ Positive trichinella skin teat } & \multicolumn{7}{|c|}{ Positive tuberculin skin test } & \multicolumn{6}{|c|}{$\begin{array}{l}\text { Negative trichinells and tuberculin skin test } \\
\text { (control) }\end{array}$} \\
\hline & \multirow{2}{*}{$\begin{array}{l}\text { Total } \\
\text { posi- } \\
\text { tive at } \\
\text { either } \\
\text { time }\end{array}$} & \multicolumn{3}{|c|}{ Flocculation } & \multicolumn{3}{|c|}{ Precipitin } & \multirow{2}{*}{$\begin{array}{c}\text { Posi- } \\
\text { tive } \\
\text { at } 24 \\
\text { hours }\end{array}$} & \multicolumn{3}{|c|}{ Flocculation } & \multicolumn{3}{|c|}{ Precipitin } & \multicolumn{3}{|c|}{ Flocculation } & \multicolumn{3}{|c|}{ Precipitin } \\
\hline & & Tested & $\begin{array}{l}\text { Posi- } \\
\text { tive }\end{array}$ & $\begin{array}{l}\text { Nega- } \\
\text { tive }\end{array}$ & Tested & $\begin{array}{l}\text { Posi- } \\
\text { tive }\end{array}$ & Nega- & & Tested & $\begin{array}{l}\text { Posi- } \\
\text { tive }\end{array}$ & $\begin{array}{l}\text { Nega- } \\
\text { tive }\end{array}$ & Tested & $\begin{array}{c}\text { Posi- } \\
\text { tive }\end{array}$ & $\begin{array}{l}\text { Nega- } \\
\text { tive }\end{array}$ & Tested & $\begin{array}{l}\text { Posi- } \\
\text { tive }\end{array}$ & $\begin{array}{l}\text { Nega- } \\
\text { tive }\end{array}$ & Tested & $\begin{array}{c}\text { Posi- } \\
\text { tive }\end{array}$ & $\begin{array}{l}\text { Nega- } \\
\text { tive }\end{array}$ \\
\hline $\begin{array}{l}\text { Orphanage } \\
\text { Prison } \\
\text { (male) } \\
\text { Prison } \\
\text { (female) }\end{array}$ & $\begin{array}{l}57 \\
53\end{array}$ & $\begin{array}{l}38 \\
44\end{array}$ & $\begin{array}{l}0 \\
4( \pm)^{*} \\
1( \pm)^{*}\end{array}$ & $\begin{array}{l}38 \\
40\end{array}$ & $\begin{array}{r}0 \\
20\end{array}$ & 0 & $4 * *$ & $\begin{array}{l}40 \\
14\end{array}$ & $\begin{array}{r}20 \\
5\end{array}$ & $\begin{array}{l}\mathbf{0} \\
\mathbf{0}\end{array}$ & 20 & $\begin{array}{l}\mathbf{0} \\
\mathbf{5}\end{array}$ & 0 & 5 & $\begin{array}{l}20 \\
31\end{array}$ & $\begin{array}{l}0 \\
0 \\
2( \pm)^{*} \\
2(3+)^{* *}\end{array}$ & $\begin{array}{l}20 \\
31 \\
16\end{array}$ & $\begin{array}{r}0 \\
18\end{array}$ & $\begin{array}{l}0 \\
0\end{array}$ & $\begin{array}{l}18 \\
14^{*}\end{array}$ \\
\hline Total & 122 & 91 & 5 & 86 & 24 & 0 & 24 & 57 & 25 & 0 & 25 & 5 & 0 & 5 & 71 & 4 & 67 & 32 & 0 & 32 \\
\hline
\end{tabular}

* Sera with doubtful ( \pm ) flocculation gave negative precipitin test.

** Sera with $3+$ flocculation gave negative precipitin test.

\section{Serologic reactions}

Orphanage. Flocculation tests for trichinosis were performed on serum from 38 children with positive trichinella skin tests, from 20 children with positive tuberculin and negative trichinella skin tests; and from 20 who reacted negatively to all antigens. All flocculation tests were negative (Table IV). No precipitin tests were done on the children.

Prison. Flocculation tests were performed on serum from 53 prisoners with positive reactions to trichinella antigen, from 5 with positive delayed tuberculin reactions, and from 51 who reacted negatively to all antigens (Table IV). Five sera from the group with positive trichinella skin tests, and 2 from the group negative to both antigens, gave doubtful flocculation reactions; 2 of the latter group gave strongly positive flocculation reactions. Precipitin tests were performed on serum from 20 prisoners with positive trichinella reactions, from 5 with positive tuberculin reactions, and from 18 who were negative to all antigens; none were positive. Serum had been collected from the other prisoners after a meal and was too cloudy for performance of accurate precipitin tests. Precipitin tests on serum from rabbits known to be infected with trichinae were strongly positive; these tests served as a control on the technique and the potency of the antigen.

\section{DISCUSSION}

No correlation has been found between the tuberculin and trichinella skin reactions; this clini- cal observation agrees with the results of experimental investigations in rabbits (3). No biologic cross reaction detectable by skin test appears to exist; the increased incidence of positive trichinella skin tests in tuberculous patients is still unexplained.

Whether the apparent increase in the incidence of positive trichinella skin tests among patients confined to any institution is connected with subclinical institutional epidemics, cannot be categorically stated. The fact that the flocculating antibodies and precipitins appear to bear no relation to positive skin reactions would argue against subclinical institutional epidemics. However, precipitins are known to persist for $2 \frac{1}{2}$ years after proven infection in human beings (5). The length of time for which flocculating antibodies persist in human beings is not known, but in swine the test remains positive for 10 months (4). It is possible that different antigens are involved in the production of the skin test and the serum reactions (6).

The increase in the incidence of positive skin reactions previously noted after 2 years' residence in an institution was confirmed at the orphanage; at the prison the peak was later, but in general the relation of positive skin tests to length of institutionalization followed the data previously reported (1). The explanation for this relationship is still obscure.

The wide variation in the incidence of positive reactions obtained in the 9 institutions which have now been studied cannot yet be explained.

While a positive tuberculin skin reaction does 
not indicate the presence of active tuberculosis, it does indicate that the individual has been infected at some time and is allergic to some fraction of the organism. It would be reasonable to expect some degree of correlation between the skin reactions to tuberculin and trichinella antigen if one disease affects the severity of the other, as was suggested by the experiments in guinea pigs previously reported (7). Perhaps active tuberculosis is necessary for the infection with trichinae to be enhanced; the present study cannot answer this question.

That tuberculosis may affect the course of trichinosis was shown also by studies of the eosinophil response of guinea pigs (8). The injection of live virulent $M$. tuberculosis depressed the number of circulating eosinophils in trichinous animals. Since a rapid rise in eosinophils is the most frequent and easily detected early laboratory evidence of uncomplicated trichinosis, the absence of eosinophilia in a tuberculous patient with a positive trichinella skin test could cause confusion in diagnosis.

It is known that the electrical resistance of the skin of disturbed mental patients may vary markedly from that of the same patient after recovery (9). Previous studies with trichinella antigen in one mental hospital suggested that the reactivity to biologic products may be altered in the same way (1). Though none of the prisoners or orphans gave a history of active mental disease, it is true that all prisoners have committed an offense and may justly be suspected of having a psychiatric disturbance. Many orphans may likewise have some mild psychiatric manifestations. None of the individuals studied was acutely disturbed, however, and hence would not be expected to have an altered skin reaction.

\section{SUMMARY}

1. No correlation between the trichinella skin test and the tuberculin reaction was found in 526 individuals confined in an orphanage or a prison. The incidence of positive trichinella skin tests in 241 prisoners was 27.8 per cent; the incidence in 285 orphans was 20.0 per cent.

2. Positive serologic reactions to the flocculation or precipitin tests were not found in persons with positive trichinella skin reactions.

3. The duration of stay in an institution is apparently a factor in determining the incidence of positive trichinella skin tests. The explanation for this finding is obscure.

\section{BIBLIOGRAPHY}

1. Harrell, G. T., and Horne, S. F., Trichinella skin tests in tuberculosis sanatoriums, hospitals for mental diseases, and general hospitals. A comparison of results in tuberculous and non-tuberculous patients. Am. J. Trop. Med., 1945, 25, 51.

2. Avera, John W., Yow, E. M., Harrell, G. T., and Fowler, E. B., An attempt by feeding to induce in animals reactivity to Trichinella spiralis in the absence of infection. Am. J. Trop. Med., 1946, 26, 125.

3. Harrell, G. T., and Helsabeck, N. I., The effect on the trichinella skin test of simultaneous infection with bovine tuberculosis in trichinous rabbits. J. Clin. Invest., 1947, 26, 69.

4. Suessenguth, H., and Kline, B. S., A simple rapid flocculation slide test for trichinosis in man and in swine. Am. J. Clin. Path., 1944, 14, 471.

5. Gould, S. E., Trichinosis. Charles C. Thomas, Springfield, Illinois, 1945, p. 143.

6. Aikawa, J. K., Harrell, G. T., and Helsabeck, N. J., The effect of peptic and tryptic digestion on the antigenicity of Trichinella spiralis. J. Clin. Invest., 1947, 26, 73.

7. Davis, O. T., Harrell, G. T., and King, E. S., The effect of simultaneous tuberculous infection on experimental trichinella infestations in guinea pigs. Am. J. M. Sc., 1945, 209, 758.

8. Spink, W. W., Effects of vaccines and bacterial and parasitic infections on eosinophilia in trichinous animals. Arch. Int. Med., 1934, 54, 805.

9. Barnell, A., Correlations between epidermal impedance and the clinical course in certain psychoses. Proc. Soc. Exper. Biol. and Med., 1939, 42, 839. 